\section{Penetrometric Measurement of Strawberry Fruit Firmness: Device Testing}

\author{
Tarja $\mathrm{H}$ ietaranta and \\ M inna-M aria Linna
}

\begin{abstract}
ADditional INDEX wORDS. Fragaria xananasa, fruit quality, puncture

Summary. The firmness of five strawberry (Fragaria xanana D uch.) varieties was determined by penetrometric method using a motorized materials testing device equipped with a 100-N load cell and a probe 6.4 $\mathrm{mm}$ (0.252 inches) in diameter. Maximum and mean forces and instant of yield point were recorded with the aim of testing the suitability of these three parameters for the assessment of fruit firmness, i.e., handling and transportation tolerance. The maximum and mean force data revealed significant differences among varieties, but instant of yield point was not reliable measurement in this test arrangement. M aximum force was the best parameter for the assessment of firmness.
\end{abstract}

irmness is an important quality factor of strawberry (Fragaria xananassa Duch.). Strawberries that aresufficiently toughskinned and firm-fleshed better tolerate handling and transportation and have longer shelf life and more attractive appearance than soft-fruited strawberries. In addition, firm-fruited varieties tend to be less susceptible to fruit rot caused by Botrytiscinerea Pers.:Fr. than cultivars with softer fruit ( $\mathrm{H}$ ancock et al., 1990; M aas, 1978).

Fruit firmness is assuming increasing importance for modern strawberry varieties. For example, 'Elsanta' has achieved the status of leading variety in western Europe (van de Weg, 1997),

Agricultural Research Centre of Finland (M TT), Plant Production Research, $\mathrm{H}$ orticulture, Toivonlinnantie 518, FIN-21500 Piikkiö, Finland.

The cost of publishing this paper was defrayed in part by the payment of page charges. U nder postal regulations, this paper therefore must be hereby marked advertisement solely to indicate this fact. largely because of its firm fruits, which have good keeping quality and transport tolerance (Terrettaz and Carron, 1991).

Strawberry firmness is affected by fruit size, stage of maturity (O urecky and Bourne, 1969; Schmitz and Lenz, 1985) and harvest day (Puchalski et al., 1994) and is composed of two factors: skin toughness and the firmness of the underlying flesh (Büttner et al., 1987). Easy and quick test methods for firmnessareneeded for quality assessment in everyday fruit production and marketing, but also for testing varieties and breeding material. Several manual and motorized penetrometric methodshave been applied to test thefirmness(Büttner et al., 1987; Kidmose et al., 1996; O urecky and Bourne, 1969; Sanford et al., 1985; Schmitz and Lenz, 1985; Schulz, 1991; Stahler et al., 1995). A motorized device has the benefit of greater operator independence $(\mathrm{H}$ arker et al., 1996), and penetration forces then depend more on the properties of the test material itself and on the form and area of the cross-section of the probe. Also microscopic methods have been used for textureevaluation of strawberries (Armbruster, 1967; Szczesniak and Smith, 1969).

The purpose of our experiment wasto test how well the different parameters-maximum and mean forces and instance of yield point- represent strawberry fruit firmnesswhen measured by a motorized materialstesting device. This kind of device has the benefit to be a rather quick way to evaluate strawberry texture.

\section{Material and methods}

Five varieties of strawberry differing in firmness- 'Elsanta', 'Korona', 'Polka', 'SengaSengana', and 'Venta'were chosen for comparison. Of these, 'Elsanta' represents the E uropean standard for good texture, while 'Senga Sengana' has long been a major commercial variety in Finland.

Strawberries, fully ripened, medium-sized, and as equal in size and form as possible, were collected and tested at threedifferent timesduring the main harvest season in J uly 1996. Twenty strawberries were measured per variety and harvest. Fruit samples were stored cold at $4{ }^{\circ} \mathrm{C}\left(39^{\circ} \mathrm{F}\right)$ immediately after picking. The penetrometric test was carried out at room temperature during the same day. Before the measurements the strawberries were taken from cold storage and halved vertically. The separately placed halveswarmed up to room temperature in 20 min.

The halving stabilized the fruit so that it would lie firmly on the measurement platform, and ensured that the measurement angle would be similar from one fruit to the next. M easurementsweredoneon thehighest point of the strawberry half, so the small differences in surface geometry caused least effect. Also none of the varieties had raised achenes. $M$ easurementswereperformed with amotorized materialstesting device (LRX; Lloyd Instruments Ltd, Fareham, E ngland) equipped with a 100-N load cell and a cylindrical probe $6.4 \mathrm{~mm}$ (0.252 inches) in diameter. The test speed wasset to $10 \mathrm{~mm} \cdot \mathrm{min}^{-1}(0.394$ inches/ $\mathrm{min}$ ) and the probe waspushed $6 \mathrm{~mm}$ (0.236 inches) into the fruit. If available a smaller load cell would have chosen, but also thisapplication seemed to work well. $M$ aximum and mean forces during the measurement from depth 0 to $6 \mathrm{~mm}$ were recorded, together with the yield point. The yield point marks the depth at which the probe begins to penetrateinto thematerial, causing irreversible crushing, and produces a clear peak in theforce-distancecurve(Bourne, 1980). In our experience, the nearer to the fruit surface that the yield point is registered (i.e., the lower the record), the better is the skin toughness. The data was subjected to analysis of variance, with the results for three harvest times, i.e., themeansof twenty fruitsper variety per harvest, treated as replicates. The means were compared by Tukey's test.

The fruit firmness was sensory evaluated by pressing the fruitsbetween fingersin theyears 1995 and 1996. The evaluation was done at two different picking times by one experienced person.

\section{Results and discussion}

The typical force-distance curve produced by thepenetrometric method was rather blunt convex in the first part, with no evident sharp yield points (Fig. 1). Probably the probe caused the skin of the strawberries first to stretch, and then to break little by little, so that the point at which the skin broke was not measured exactly. O ften the yield point was registered at the same depth from the fruit surface where the maximum forcewasregistered, or at least near to it. The general blunt shape of the forcedistance curves made the interpretation 


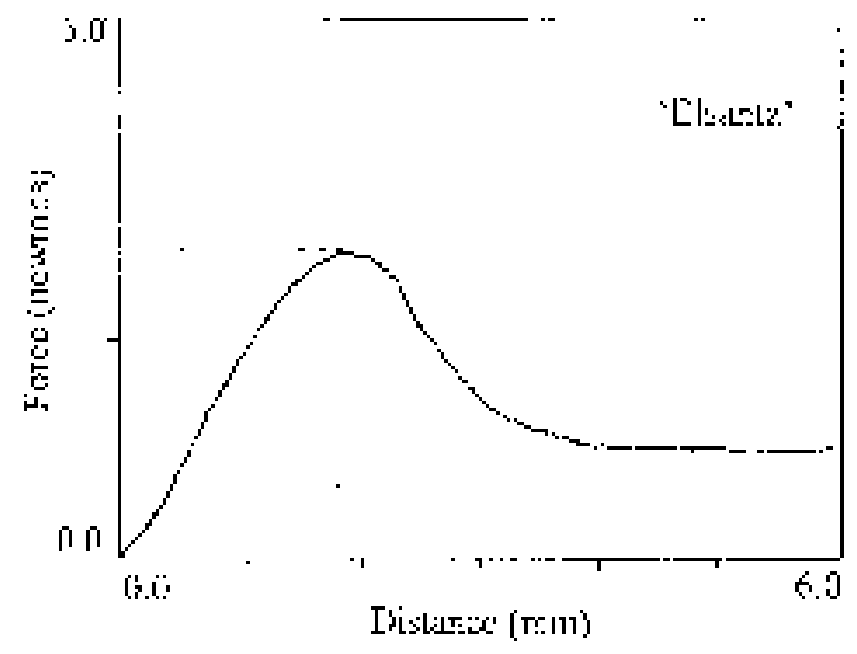

Fig. 1. Typical force-distance curves for 'E Isanta' and 'Venta'. N ote the lack of sharp force maximums.

of thisparameter unreliable; in addition, the yield point data were not normally distributed. Themeasurementsof maximum force and mean force were more reliable. I n our opinion, maximum force expresses in this case mainly the combined effect of skin toughness and the firmness of the flesh just beneath the skin. M ean force, in turn expressesmainly the flesh firmness, but with some influence of skin toughness. $\mathrm{H}$ ad the probe reached the bundle zone, which is tougher tissue, it would have shown as rising in the ends of the force distance curves. Thishappened only in few cases. The measurement to a depth of 4 to 5 $\mathrm{mm}$ (0.157 to 0.197 inches) would have totally prevented the possibly of this distortion.

The measurement of yield point would probably better have reflected skin toughness if the probehad been of smaller diameter. The large, 6.4-mm probe was chosen for technical reasons. The device has an option that measurement will not commence before the probe touches the sample surface, i.e., some resistance is encountered. This automatically provides for more reliable measurements from the surface to a certain depth, here $6 \mathrm{~mm}$. When the measured forces are very small, as they are when small probes are used for strawberries, the automatic feature fails. The 6.4-mm probe increased the forces sufficiently for the automatic feature to work. Choice of this probe thus facilitated more accurate mean load measurements.

Both themaximum and mean force data revealed significant differences between varieties, but the differences in maximum forceweremorepronounced (T able 1). O verall, the maximum force resultswere consistent with our sensory evaluations (Table 1 ) and with reports in the literature. Contrary to expectation, the difference in maximum force data between 'Elsanta' and 'Polka' was not significant. 'Elsanta' has been reported to befirmerthan 'Polka' (M öhler, 1996). The good texture of 'E Isanta' is mostlyrelated to skin toughness; Büttner et al. (1987) found that the skin toughness was better for 'Elsanta' than for 'Korona' or 'SengaSengana', whilethere was no difference in flesh firmness. $\mathrm{O}$ ur data are not consistent with the results of Kidmose et al. (1996); for in their results 'Elsanta' appears as even softer than 'Korona' and 'Polka'. H owever, they found like us that 'Senga Sengana' was softer still. The reason for the different results may be that the firmness data of Kidmose et al. (1996) express merely flesh firmness. I n our experiment, 'Senga Sengana' and 'Venta' werethetwo softest varieties as expected; 'Venta' has been reported to be a very soft-fruited variety (Trajkovski, 1996).

The mean force results, which mostly express the flesh firmness, were in the same general direction as the maximum force results, but fewer significant differences were distinguished among the varieties (Table1). The only indication was that 'Venta' was softer than 'E Isanta', 'Korona' and 'Polka'.

To conclude, thesuitability ofmaximum and mean forces and instant of yield point measurementswastested for the assessment of strawberry firmness. $M$ aximum force valuesproduced by the method gave a better picture of the varietal firmness differences than did mean force results. The yield point recognition appeared not to work in this application in which the probediameter was $6.4 \mathrm{~mm}$. The use of a smaller probe probably would have produced more reliable results for this parameter.

\section{Literature cited}

Armbruster, G. 1967. Cellular and textural changes in three varieties of strawberries as a result of pre-freezing treatments. Proc. Amer. Soc. H ort. Sci. 91:876-881.

Bourne, M.C. 1980. Texture evaluation of horticultural crops. H ortScience 15:51-57.

Table 1. Maximum and mean force and yield point $(n=3)$ records from penetrometric measurements ( mean \pm SE) of five strawberry varieties.

\begin{tabular}{lccccc}
\hline & $\begin{array}{c}\text { Maximum } \\
\text { force } \\
\text { Variety }\end{array}$ & $\begin{array}{c}\text { Mean } \\
\text { force } \\
\mathbf{( N )}\end{array}$ & $\begin{array}{c}\text { Yield } \\
\text { point } \\
\text { (mm) }\end{array}$ & \multicolumn{2}{c}{$\begin{array}{c}\text { Sensory } \\
\text { scores }^{2}\end{array}$} \\
\hline Elsanta & $2.76 \pm 0.08 \mathrm{a}^{\mathrm{y}}$ & $1.48 \pm 0.06 \mathrm{a}$ & $1.44 \pm 0.03$ & 7.5 & 7.5 \\
Polka & $2.38 \pm 0.09 \mathrm{ab}$ & $1.41 \pm 0.05 \mathrm{a}$ & $1.49 \pm 0.04$ & 7.0 & 7.0 \\
Korona & $2.18 \pm 0.13 \mathrm{~b}$ & $1.36 \pm 0.08 \mathrm{a}$ & $1.76 \pm 0.09$ & 7.0 & 7.0 \\
Senga Sengana & $2.08 \pm 0.04 \mathrm{bc}$ & $1.21 \pm 0.03 \mathrm{ab}$ & $1.80 \pm 0.08$ & 5.5 & 5.5 \\
Venta & $1.75 \pm 0.09 \mathrm{C}$ & $1.06 \pm 0.06 \mathrm{~b}$ & $1.60 \pm 0.10$ & 4.0 & 4.5 \\
F values & $16.24^{* * *}$ & $8.01^{* *}$ & & &
\end{tabular}

${ }^{2}$ Score $=$ nine-point reference $(9=$ very firm, $5=$ average, $1=$ very soft $) . M$ eans of evaluations of two different picking times per year.

$M$ eans marked with the same superscript do not differ at $P \leq 0.05$, Tukey's procedure.

${ }^{* *, * * *}$ Significant at $\mathrm{P}<0.01$ or 0.001 , respectively. 
Büttner, R., K. U hlemann, and P. Schulze. 1987. Penetrometrische Festigkeitsuntersuchungen an Früchten eines Erdbeersortimentes. Arch. Gartenbau 35:115-128.

H ancock, J.F., J.L. M aas, C.H. Shanks, P.J. Breen, and J.J. Luby. 1990. Strawberries (Fragaria), p. 489-546. In: J.N . M ooreand J.R. Ballington, Jr. (ed.). Genetic resources of temperate fruit and nut crops. Intl. Soc. H ort. Sci., Wageningen.

H arker, F.R., J.H . M aindonald, and P.J .J ackson. 1996. Penetrometer measurement of apple and kiwifruit firmness: O perator and instrument differences. J. Amer. Soc. H ort. Sci. 121:927-936.

Kidmose, U ., H . Andersen, and O . V ang-Petersen. 1996. Yield and quality attributes of strawberry cultivars grown in Denmark 1990-1991. Fruit Var. J. 50:160-167.

M aas, J.L. 1978. Screening for resistance to fruit rot in strawberries and red raspberries: A review. H ortScience 13:423-426.

Möhler, M. 1996 Vergleich von sieben Erdbeersorten im ersten Ertragsjahr. O bstbau 21:299-300.

O urecky, D.K. and M.C. Bourne. 1968. Measurement of strawberry texture with an Instron machine. Proc. Amer. Soc. H ort. Sci. 93:317325.

Puchalski, C., J. Gorzelany, and Z. G oracy. 1994. The effect of maturity and harvest date on firmness of strawberry fruit. Zemedelska Technika 40:33-43.

Sanford, J.C., D.K. O urecky, and J.E. Reich. 1985. 'J ewel' strawberry. H ortScience 20:11361137.

Schmitz, F. and F. Lenz. 1985. Einfaches G erät zur messung der Festigkeit von Erdbeerfrüchten. Gartenbauwissenschaft 50:261-264.

Schulz, H. 1991. Bestimmung der Gewebefestigkeit von Kernobstfrüchten mit einem mechanisch arbeitendem Penetrometer mit M otorantrieb I. Beschreibung desPenetrometers mit M otorantrieb. Gartenbauwissenschaft 56:279-282.

Stahler, M .M ., F.J . L awrence, L.W. M artin, P.P. M oore, H.A. D aubeny, W.A. Sheets, and G.W. Varseveld. 1995. 'Redcrest' strawberry. H ortScience 30:635-336.

Szczesniak, A.S. and B.J . Smith. 1969. O bservation on strawberry texture a three-pronged approach. J. Texture Studies 1:65-89.

Terrettaz, R. and R. Carron. 1991. Essai de varietes de fraisiers en montagne. Revue suisse de viticulture a'arboriculture et d'horticulture. 23:249-251.

Trajkovski, K. 1996. Strawberry breeding (in Swedish), p. 30-33. In: Balsgård-Report 19921994. Balsgård, Swedish U niv. Agr. Sci.

Van de Weg, W.E. 1997. Gene-for-gene relationshipsbetween strawberry and thecausal agent of red stele root rot. Phytophthora fragariae var. fragariae. Thesis Wageningen.

Hortlechnology • J anuary-M arch 1999 9(1) 